\title{
Urdimento
}

Revista de Estudos em Artes Cênicas

E-ISSN: 2358.6958

\section{OECD and Theatre Education}

Interview with: Andreas Schleicher, Stéphan Vincent-Lancrin, Ellen Winner, Thalia Goldstein granted to André Luiz Lopes Magela

\section{Para citar este artigo:}

MAGELA. André Luiz Lopes. OECD and Theatre Education. Interview with: Andreas Schleicher, Stéphan Vincent-Lancrin, Ellen Winner, Thalia Goldstei. Urdimento, Florianópolis, v. 3, n. 39, nov./dez. 2020.

DOI: http:/dx.doi.org/10.5965/14145731033920200502 


\title{
OECD and Theatre Education
}

Interview with: Andreas Schleicher, Stéphan Vincent-Lancrin, Ellen Winner, Thalia Goldstein granted to André Luiz Lopes Magela ${ }^{1}$

\begin{abstract}
Written interview in May 2020 with Andreas Schleicher, director of education at the OECD - Organization for Economic Cooperation and Development, focusing on educational issues that directly or indirectly concern theatre education. The interview was also addressed to Stéphan Vincent-Lancrin, Ellen Winner and Thalia Goldstein, authors of an OECD book dedicated to teaching arts in schools. The approached topics comprehended the importance of artistic education, connections of artistic education with competencies, public policies in education and the global economic agenda. The interview is preceded by a preamble authored by the interviewer.
\end{abstract}

Keywords: OECD. PISA. Theatre education. Education policies. Andreas Schleicher

\section{OCDE e Educação Teatral}

\begin{abstract}
Resumo
Entrevista realizada por escrito em maio de 2020 com Andreas Schleicher, diretor de educação da OCDE - Organização para a Cooperação e Desenvolvimento Econômico, enfocando questões educacionais que direta ou indiretamente dizem respeito à educação teatral. Foram também entrevistados Stéphan Vincent-Lancrin, Ellen Winner e Thalia Goldstein, autores de livro da OCDE dedicado ao ensino de artes em escolas. Os assuntos abordados giraram em torno da importância da educação artística, conexões da educação artística com competências, políticas públicas em educação e agenda econômica mundial. A entrevista é precedida por uma apresentação de autoria do entrevistador.
\end{abstract}

Palavras-chave: OCDE. PISA. Educação teatral. Políticas educacionais. Andreas Schleicher. 


\section{OCDE y Educación Teatral}

\section{Resumen}

Entrevista escrita, producida en mayo de 2020 con Andreas Schleicher, director de educación de la OCDE - Organización para la Cooperación y el Desarrollo Económicos, centrada en cuestiones educativas que directa o indirectamente se refieren a la educación teatral. Algunas de las preguntas también fueron dirigidas a Stéphan Vincent-Lancrin, Ellen Winner y Thalia Goldstein, autores de un libro de la OCDE dedicado a la educación artística en las escuelas. Los temas comprendieron la importancia de la educación artística, conexiones entre la educación artística con competencias y políticas de educación pública relacionadas con la agenda económica mundial. La entrevista es precedida por un preámbulo escrito por el entrevistador.

Palabras clave: OCDE. PISA. Educación teatral. Políticas educativas. Andreas Schleicher. 


\section{Urdimento}

Presentation

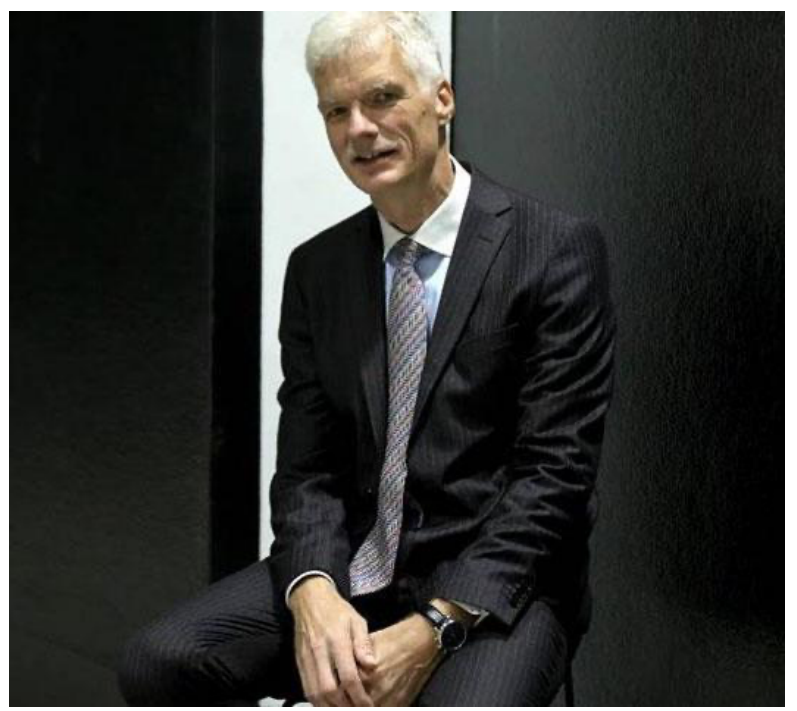

Andreas Schleicher²

My interest in Andreas Schleicher arose when I became aware of a speech he made in the House of Commons, in England, in February 2019. Schleicher was invited to talk about education challenges in the face of the technological changes in the world and, at one moment, he stated categorically to British parliamentarians: "in the fourth industrial revolution, art may become more important than maths." (United Kingdom, 2019).

Because of this so peculiar sentence, and also apparently so hopeful for the field of artistic education, I began to intensely investigate his work ${ }^{3}$. Because the person who was saying that was not an arts education professional, but someone in charge of organizing worldwide information on education aimed at economic development. And someone who is heard, quite heard.

${ }^{2}$ And Schleicher was born in Germany and has a degree in physics and mathematics. He is director of the OECD Directorate for Education and Skills and coordinates PISA. https://www.prisa.com/pt/noticias/noticias1/andreas-schleicher-responde-a-las-preguntas-de-profesores-alumnos-y-familias.

${ }^{3}$ Issues addressed in a recent article of mine, "Refusal and adherence: resistance between studies of cognition and theatre education", submitted for publication. 
Andreas Schleicher is the Director of Education and Skills of the OECD Organization for Economic Co-operation and Development, an international organization that promotes, among other initiatives, the PISA - Program for International Student Assessment (the global test for education). This directorate is responsible for many publications on education in general, and some that directly or indirectly addresses artistic education. Schleicher is the author of several books based on the data produced by OECD actions and is invited by many countries and institutions to talk about education issues.

In these twenty years of PISA application, perhaps we can establish a progressive line of change, in which, in the beginning, the idea of putting education in the first place was sometimes seen as something strange or exaggerated. Today this idea seems to have been more accepted worldwide, even if it has not yet been put into practice in a sufficiently comprehensive way. Schleicher's sentence on art, in the British parliament, suggests that perhaps we can think of a time when the idea of prioritizing artistic education is reasonable.

In contact with OECD's education bibliography and with the many interviews that Schleicher has given, I see an opportunity to build a time when arts classes will have a greater and effectively important participation in the social dimensions linked to what is considered essential - even the very survival domain. This was my initial motivation to propose this interview.

I also notice a glaring gap in information about OECD in our academic circles. I have been surprised in recent months by the question "what is OECD?" coming from many of my colleagues and other people involved in education. Whether there is adherence or resistance to these ideas and policies promoted by OECD and other organizations in this kind of world action, I stress that the need to know these influences, which are not small, is unequivocal and urgent. On this subject, I recommend some literatures critical to OECD actions, or those considered similar: (Pereira, 2019), (Biesta, 2018), (Laval, 2007), (Ydesen, 2019). I do not think it is necessary here to recommend specific literature in favour of these policies, since 
I already strongly recommend the consultation of the OECD material itself $f^{4}$, with particular attention to Schleicher's most recent book (2018), also available in Portuguese.

There are other elements in the scopes focused here that I consider relevant to theatre education. Schleicher's ideas seem to contemplate a more contemporary philosophical view (present in authors such as Gilles Deleuze and Félix Guattari), where we see the world not in terms of previously defined objects, but as relationship nets, as movement and as a complex articulation of forces and forms (what we might call 'intensive approach'). One example is the teaching of historical facts and dates losing space for a consistent understanding of the social forces that make up history. Or if we propose that the teaching of theatre does not concern so much the theatre already instituted and performed by professionals, but to a theatricality (or performativity) in the broadest meaning, to a theatrical relation to life. Citing a statement of Schleicher, to realize that teaching mathematics does not consist of a fixation of mathematical formulas, but rather to think mathematically in all spheres of life (theatre plots are mathematical - for example, in understanding causality, verisimilitude and hierarchies of importance of events).

Similarly, I see, in this corpus of speeches and written works about education, even if they are closely related to the economic discourse, an opportunity to support, in theatre education, the more recent conceptual tendencies linked to the so called Embodied Cognition (Lakoff, 1987) (Johnson, 1987) (Varela, Rosch, Thompson, 1992). Assuming this manner to deal with human cognition, we rethink traditional conceptions about relationships between body, brain and mind. Furthermore, in these recent conceptions, there is almost a fusion of the aspects named as rational to the emotional ones. If we succeed to make these perspectives to be taken into account in education, we may contribute to establishing the importance of theatre classes that expand the theatrical thinking of students, once it is, in a complex way (but saying it in 'old', even obsolete,

${ }^{4}$ https://www.oecd-ilibrary.org/education . 
terms), rational, cognitive, mental, corporeal, emotional.

In this respect, we should pay attention to the emphasis, present in Schleicher's speeches and in many OECD materials, for what they call, among other terms, social or interpersonal and emotional skills ${ }^{5}$. Andreas Schleicher, in a speech twelve years ago, mentioned the fact that "these skills are seldom taken into account in admission decisions". He also noted that these skills are not easily translatable into numbers ${ }^{6}$.

But nowadays, even if in a still incipient way, we can say that the set of social or interpersonal and emotional skills is no longer a mere base, or background dimension - something that is only noticed when it is missing or it malfunctions, a substrate whose possession is necessary only to ensure the skills that have always mattered: those superficially or immediately associated with jobs. Today they are more considered in some places and perhaps these skills will be at some moment the main material of pedagogical work and educational evaluation processes. The OECD's 2015 book about social and emotional skills is a movement in this direction, in terms of including, in the thoughts about measurements of education outcomes and improvement of pedagogical strategies, complex elements that previously could not be measured.

Anyway, the market is already absorbing this sphere. Last year, for example, IBM published a report, coordinated by Amy Wright, addressing what they assume as skills needed for people dealing with devices that use Artificial Intelligence. Harmoniously to other ideas already stated in the management and human resources area, the report indicates that the importance of behavioral skills is increasingly in evidence.

This is not yet systematically worked on, but these elements (interpersonal skills, perspectivation and complex understanding of situations, 'personalization', agency, emotional self-regulation, adaptation and flexibility, cooperation, and

${ }^{5}$ While I recognize advantages in these OECD materials, I do not adopt the epistemology interweaved with this type of categorization.

${ }^{6}$ PISA works essentially with statistics (and it is their main instrument of persuasion). Hence the concern to convert phenomena into numbers. 


\section{Urdimento}

teamwork) can be considered as present intrinsically in a qualified pedagogical practice of theatre. The recent promotion of creativity, in its relationship with theater classes, configures an example of action in this logic.

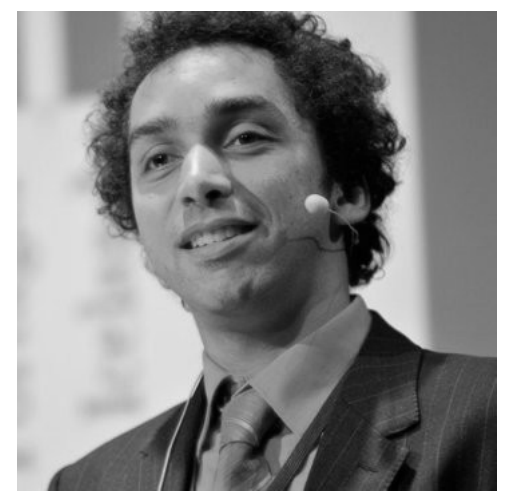

Stéphan Vincent-Lancrin ${ }^{7}$

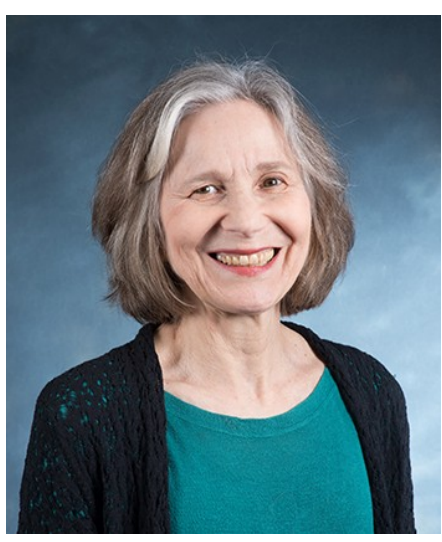

Ellen Winner ${ }^{8}$

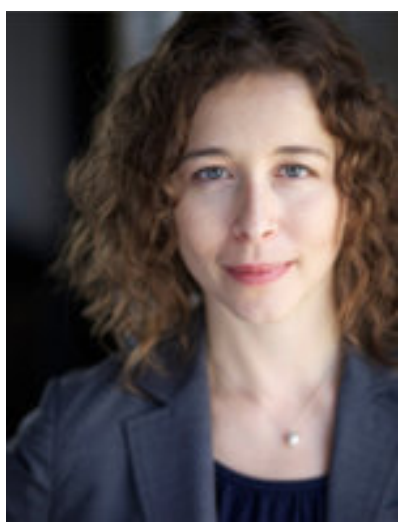

Thalia Goldstein ${ }^{9}$

Trying to contemplate some particularities of this field, I invited other people

\footnotetext{
${ }^{7}$ Is French, senior analyst at the OECD's Centre for Educational Research and Innovation (CERI). He holds a $\mathrm{PhD}$ in economics and a master's degree in business administration and philosophy. https://fr.linkedin.com/in/stephan-vincent-lancrin

${ }^{8}$ Is a psychologist, professor at Boston College, specializing in art psychology. She collaborated on Harvard University's Project Zero, a research project on arts and cognition active since 1967. https://www.bc.edu/bcweb/schools/mcas/departments/psychology/people/faculty-directory/ellen-winner.html

${ }^{9}$ Is assistant professor of applied developmental psychology at George Mason University - USA. Her work focuses on how social and emotional skills in children connect with engagement in make-believe games, theatre, drama, and other imagination activities. Several of his articles are available for download athttps://www.researchgate.net/profile/Thalia_Goldstein/research. https://www.researchgate.net/profile/Thalia Goldstein
} 
involved in OECD publications, Ellen Winner, Thalia Goldstein and Stéphan VincentLancrin $^{10}$, to whom I addressed more specific questions. Thalia Goldstein took the opportunity to recommend articles of her authorship that connect interpersonal skills, perspective-making and self-regulation with theater classes (available for download ${ }^{11}$ ), as well as a book on pedagogies based on theater teaching ${ }^{12}$.

The questions address, as much as possible, ethical and political issues that intrinsically permeate the association between education and economic development.

We can find, in OECD educational material, an explicit choice to lessen the influence of intuition and previous assumptions and the importance of making evidence-based decisions on the data produced by PISA. The clue is to measure and examine what has already worked well - decisions and strategies related to or that caused successful experiences.

But at the same time, Schleicher observations and OECD publications go beyond that, composing a body of thoughts and ideas about education which ultimately sets up guidelines and recommendations on what to do to improve each country's results in education tests. In a certain way, this states a position, a philosophical body of actions on education, articulated in "theoretical and conceptual foundations", as Schleicher once said.

The book on skills for 2030 presents a very wide-range view on education in the last 200 years, addressing, in a critical way, political issues and imaginary frames associated with production and capitalism. Most of the recommendations present in Schleicher's (2018) recently published book about PISA (e.g. education for all, to welcome differences and caring more for those who have difficulties), are well-tuned with the idea of a State of social well-being and strict and effective control of predatory capitalism. Essential points on reducing inequality are very

10 These three authors produced the book "Arts for art sake" by the OECD in 2013.

${ }^{11}$ https://www.researchgate.net/profile/Thalia_Goldstein/research

12 I also suggest a French reference on this topic: studies by Marie-Christine Bordeaux on research that attempts to evaluate the effects of artistic and cultural education in France. (Bordeaux, 2016). 
controversial in people's economic and social imaginary...

In the wake of this latest topic, the ethical one, many of OECD analysis concern on how to encourage teachers and students to have more motivation for education (with particular attention to those who struggle in this process). We can mention some references, present in Schleicher's book: to allocate the professionals with better results to schools whose students have more difficulties; the non-separation between students with difficulties and those with good grades; to invest more time and attention on students with difficulties; the importance of valuing the teacher and their collaborative work. More dedicatedly, we have the 2017 book on "Student's well-being", in which "attitudes, disposition, mental strategies, ability to deal with life" are addressed. We can, in an audacious way, associate one expression mentioned by Schleicher, "translate intentions into actions", with the concept of agencement (arrangement or assemblage), central to the philosophy of Gilles Deleuze and Félix Guattari, and strongly linked to our ability to establish pertinent and powerful links with life. Apparently in great affinity with this, Alain de Botton, citing an example with another type of approach, defends the centrality of an Emotional Education in educational systems.

Going deeper in this theme, the final questions refer to teachers' continuous training, in their need to articulate (to manage) openness to what's new, 'against' a fidelity to what is important to remain; to evaluate what 'serves' and should be maintained facing what can and/or must be changed or extinguished. Students and teachers need a strong capacity to adapt if they aim to fulfill the everchanging demands of the economic world (or at least to survive them...). And, at the same time, they shall pay attention to which practices and values must be maintained (e.g. cultural traditions and deeper social values - ethical ones and those who give meaning to life).

But the education approach that focuses on (or takes as an objective) the economic agenda implies the articulation between social responsibility and immediate or self-centered interests of agents who hold more economic power. What's at stake, and under threat, is long-term collective interests that contemplate deeper values and needs of societies. Few factors prevent that the 
attitude of healthy awareness (maybe concern) and constant learning fall into a fetish for innovation and a devaluation of important personal-cultural characteristics of those involved in these processes.

Finally, and resuming the initial motive for proposing this interview, the main purpose here is not to advertise positive points of the material mentioned here as reasons for joining it. The intention is to take advantage of this character, extracted from these OECD materials, of social commitment and appreciation of the artistic dimension. And this perspective may contribute to pressure the social actors who have decision-making power over education, so that they adopt more measures promoting a comprehensive social well-being, in our case, with regard to theatre education.

The argument envisioned is that our positioning is not only ideological, as it has been attacked more than ever, but that working in theatre education can also contribute to claims associated with economic development. This interview aims to collaborate with information that can fuel this form of resistance, encouraging teachers and other education professionals to further research these materials that have been used as determinants for education.

\section{The Interview}

Would it be possible to think of a future moment where the idea of "arts education first" could be disseminated worldwide? Would there already be drafts of how this could be encouraged or implemented? How is your perception of the reception, by education professionals and students in the world, of this view that arts are more important in education than common sense considers?

Andreas Schleicher - Well, these days, education is no longer just about teaching students something, but about helping them develop a reliable compass and the tools to navigate with confidence through an increasingly complex, volatile and uncertain world. Success in education today is about identity, it's about agency and it's about purpose. It's about building curiosity - opening minds, it's about compassion - opening hearts, and it's about courage, mobilizing our cognitive, social and emotional resources to take action. And that's also going to be our best 
weapon against the biggest threats of our times - ignorance - the closed mind, hate - the closed heart, and fear - the enemy of agency. All this shows why the arts have become so central for education.

We live in this world in which the kind of things that are easy to teach and test have also become easy to digitize and automate. The future is about pairing the artificial intelligence of computers with the cognitive, social and emotional skills and values of human beings. It will be our imagination, our awareness and our sense of responsibility that will enable us to harness technology to shape the world for the better.

The bottom line is, if we want to stay ahead of our times, we have to find and refine the qualities that are unique to our humanity, and that complement, not compete with, capacities we have created in our computers. Schools need to develop first class humans, not second-class robots. Education has made great strides to help us understand the world around us and even explore far-away planets. It is time that education helps us better understand our own minds and experiences. And we better understand our minds before some algorithm will make our minds up for us.

All of this has brought the arts and arts education from the periphery to the centre of education. And the arts open doors to other fields of knowledge too.

Ellen Wainer - I am not at all optimistic that arts education will come to be considered more important than all other subjects. But I certainly believe it AS important. I do not think that there has been much change in the perception of education professionals about this. The arts are still seen as extras.

This question is specially addressed to Andreas Schleicher: You studied at a Waldorf school for a significant period of your life. What was the influence of this pedagogy on the way you perceive the teaching of arts? Would the teaching of theatre in Germany, with its theatrepädagogik, or the idea of building, also influence your trajectory? Could you comment or suggest on other influences in the world that could contribute to seed, in people's imaginary, a more important consideration about arts in education?

Andreas Schleicher - Yes, the Waldorf school will have played an important 
part for me to experience and recognize the value of the arts. But I was also fortunate to play in a youth orchestra with a conductor who was one of the most amazing educators I have ever met. He taught us to listen, to become mindful, to see us become part of a bigger picture, to value perfection, and to practice with diligence and persistence not just at school but also at home. And perhaps most importantly, music taught me to love learning. And later on I travelled the world with the orchestra and perhaps that's why I got interested in working internationally. And finally I even became a good student.

And that's a lot more than a personal experience. A growing body of research shows how skills in the arts relate closely to other important human capabilities. For example, music education has been empirically shown to strengthen academic performance, word decoding and phonological skills and there is evidence that music education might facilitate foreign language learning.

Theatre education, for example through enacting stories in the classroom, has been shown to strengthen verbal skills, and students who study the visual arts are stronger in geometrical reasoning than students who do not study the visual arts. And studies have shown that instruction in dance improves visual-spatial skills.

And even if arts education did not contribute to any academic outcomes, arts education should still have an important place in our schools, simply because of the importance of art as a human experience. Any of us would have difficulties imagining a good life without the arts and some cultural awareness.

Of course, knowing about the importance of arts education is one thing, but designing and delivering innovative and effective arts education is quite another thing. The arts can be taught in a way that enhances human qualities, or they can be taught poorly. What I mean is that, as important as the curriculum is, we need to better understand the pedagogies and attitudes that lead to better outcomes.

There is an emphasis in PISA on the idea to not be directed to the knowledge that the student holds, but to what he can do with what he knows. This seems to be quite pragmatic, in a context with excess and easy access to information, but where what really will matter is the relationship that the student establishes with this data. At the same time, it contemplates a more contemporary conception of learning, as something of the order of the procedural - the process that is built with the student. 
Taking this into account, how do you perceive the understanding and adherence, by teachers, students and other social actors of education, of this perspective of educational content as something of the order of the operational, the intensive, the relational, and not as mere information?

Andreas Schleicher - Of course, state-of-the-art knowledge will always remain important. Innovative or creative people generally have specialized skills in a field of knowledge or a practice. As important as it is to learn how to learn, we always learn by learning something. But success in educational is no longer mainly about reproducing content knowledge; it is about extrapolating from what we know and applying that knowledge creatively in novel situations. Epistemic understanding - e.g. thinking like a scientist, philosopher or mathematician - is taking precedence over knowing specific formulae, names or places. Similarly, history is not primarily about remembering dates, names and places but about being able to think like an historian, i.e. understand how the narrative of a society has emerged, developed, advanced, and sometimes unraveled when the context changes. So schooling today needs to be much more about ways of thinking (involving creativity, critical thinking, problem-solving and judgement), ways of working (including communication and collaboration), tools for working (including the capacity to recognize and exploit the potential of new technologies) and about the capacity to live in a multi-faceted world as active and responsible citizens.

The conventional approach in school is often to break problems down into manageable bits and pieces and then to teach students how to solve these bits and pieces. But modern societies create value by synthesizing different fields of knowledge, making connections between ideas that previously seemed unrelated. That requires being familiar with and receptive to knowledge in other fields.

In today's schools, students typically learn individually and at the end of the school year, we certify their individual achievements. But the more interdependent the world becomes, the more we need great collaborators and orchestrators. Innovation is now rarely the product of individuals working in isolation, but rather an outcome of how we mobilize, share and integrate knowledge. The well-being of societies depends increasingly on people's capacity to take collective action. Schools therefore need to become better at helping students learn to develop an 
awareness of the pluralism of modern life. That means teaching and rewarding collaboration as well as individual academic achievement, enabling students both to think for themselves, and to act for and with others.

OECD's education works frequently stress the need to base educational decisions on evidence. Still, there is, articulated with this understanding, in the written works and interviews that derive from PISA, a whole body of explicit and implicit recommendations. Inevitably, these analyses and recommendations are associated with an ethical positioning. In fact, there is a strong connection, in this material, to ethical and personal components related to the individuals involved in education. To give a central relevance to the ethical scope is also, inevitably, to take a position. To compose or adopt a philosophy or system of ideas - an ideology, some would say.

How were this processes of emergence of this perception (the importance of the ethical dimension), to assume this position and to weave a discourse and line of actions to validate it? To what extent and in what ways do you see the ethical issue in education and in the future professional life of students as 'technical', as a pragmatism (to teach cooperation, for example)? Can this dimension be translatable in objective or measurable terms?

Andreas Schleicher - That seems to be the toughest challenge in modern education: how to incorporate values into education. Values have always been central to education, but it is time that they move from implicit aspirations to explicit education goals and practices in ways that help communities shift from situational values - meaning "I do whatever a situation allows me to do" - to sustainable values that generate trust, social bonds and hope. If society doesn't build foundations under people, many will try to build walls, no matter how selfdefeating that would be.

Trying to limit education to the delivery of academic knowledge carries the risk that education ends up dumbing people down to compete with computers, rather than focusing on core human traits that will enable education to stay ahead of technological and social developments. Ask yourself why it is so much easier for digital technologies to replace today's knowledge workers rather than yesterday's hunter-gatherers. The answer is that in Taylorising work organization and specializing human skills, we have lost many of the human capabilities that may have no direct instrumental value at work. 
Right in the first paragraph of the "OECD Learning Compass 2030", it is stated that education should primarily encourage students to "understand and appreciate different perspectives and worldviews, interact respectfully with others, and take responsible action toward sustainability and collective well-being". How has been your perception, over time and in the different regions of the world, about the understanding and acceptance of principles like these? And in situations where they are well received, what have been the strategies of implementation of these ideas?

Andreas Schleicher - Singapore was the first country I came across that places values explicitly at the centre of its curriculum framework. It emphasizes respect, responsibility, resilience, integrity, care and harmony in school. These values are meant to shape students' character qualities, such as self- and social awareness, relationship management, self-management and responsible decision making. In fact, this framework refers to character qualities as "values in action".

As a whole, the Singaporean curriculum framework is designed to nurture a confident person, a self-directed learner, a concerned citizen and an active contributor. Singapore's schools use the framework to design curricular and cocurricular programmers that will help students develop the requisite competencies. In addition, every student is expected to participate in "Values-inAction" programmers that help build a sense of social responsibility. Still, even in Singapore, much of this remains an aspiration that is at best only partially reflected in how students actually learn and teachers actually teach.

While the case for creating and implementing a new 21st-century curriculum is strong, there seems to be an equally strong alliance standing in the way of change. Parents who worry that their child will not pass an exam may not trust any approach that promises to achieve more with less. Teachers and their unions may worry that if they are asked to teach more subjective material, such as social and emotional skills, they will no longer be assessed just for what they teach but also for who they are. School administrators and policy makers may feel that they will no longer be able to manage schools and school systems when the metric for success shifts from easily quantifiable content knowledge to certain human qualities that may not reveal themselves in full until well after their students graduate. Developing convincing responses to these concerns will require a courageous approach towards the design of modern curricula and assessments. 
Devising school curricula for the next generation that move beyond past experience will therefore require extraordinary leadership. It will involve explaining and advocating for study plans and assessments that prioritize depth of understanding, and encourage breadth of engagement in learning across the community.

There are still many difficulties in the measurement and systematic treatment of the set of social or interpersonal and emotional skills and, if we follow the idea, central in PISA, that evaluation is the first step to make something better, there is still much to do in this field. Considering this issue, how is today this process of improving precision in the approach to these non-routine and interpersonal elements? What are the prospects in this field?

Ellen Winner - I am not an expert in the assessment of social and emotional skills but there are certainly new measures that have been developed for this purpose. I cannot speak to how precise these are but I am always skeptical that a self-report measure is a good measure. Best to have both teachers and parents and peers rate the same child.

If we consider these 'soft skills', and the existence of skills directly linked to the arts in general and theatre skills (operating in everyday life, it must be clear), I ask: is there or could there be any way to include in PISA some ways of evaluation other than by writing? Something corporal, for example? Group dynamics?

Ellen Winner - This is an interesting idea. I suspect it would be hard to assess in a reliable way though.

The 2013 OECD book Arts for art's sake, written by you, addresses arts classes adopting, as its core approach, the transfer of skills (e.g., arts classes helping with language and math outcomes) ${ }^{13}$. Do you know or foresee other ways of measuring and fostering artistic and theatrical skills, autonomous ways that see these skills as an end in themselves within the context of education?

Ellen Winner - Certainly we can assess learning in an art form. This is much

${ }^{13}$ As we will see below, my question was not sufficiently well formulated. Because the interview was written (what makes difficult the reversibility in the dialogue), I preferred to maintain this imprecision and to paste here a brief synthesis of the book, taken from the OECD site: "Arts education is often said to be a means of developing critical and creative thinking. This report examines the state of empirical knowledge about the impact of arts education on these kinds of outcomes." 
easier to do than trying to demonstrate transfer -- which is notoriously hard to demonstrate.

Stéphan Vincent-Lancrin - The book argues that arts classes should primarily be held to foster skills in the arts and that the proper way to measure their success is whether they meet this goal. However, there is an interest also about the state of contribution of the arts to other subjects or to other kinds of skills such as creativity and critical thinking. We showed where the research was, and what kind of outcomes were found by strong research designs. It is astonishing that so much research on arts education focuses on this transfer question, and so little on artistic outcomes. Even on creativity, a subject that most arts educators feel they have a lot to contribute, there is little research - and in fact too little to conclude anything. Theatre education actually had one of the strongest results as it clearly allowed for the acquisition of verbal skills when texts where played as drama in class.

In our work that followed on the fostering and assessing of creativity and critical thinking (Vincent-Lancrin et. al., 2019) (which was just released in 2019 and for which the Ayrton Senna Institute did a Portuguese translation and a conference last March in Sao Paulo), we worked in STEM ${ }^{14}$ education and in arts education, and we developed specific achievement tests in music and in visual arts (with the additional difficulty that they were international and could not be on artistic culture). This shows that arts education can be measured and assessed through the lens of developing artistic skills. We did not have theatre education, and perhaps it would have been more difficult to do, but we haven't tried anyway. Basically, what we tried to do in those two areas was to see how much knowledge of technical vocabulary students had, how much they could see or learn, to what extent they could see or hear the emotions that were (in principle) expressed by pieces of music or visual arts, and what they knew about it as an art form in general. We did two versions, one for primary school and one for secondary school students.

${ }^{14}$ Group of disciplines composed of Science, Technology, Engineering, and Mathematics. 
Thalia Goldstein - I don't think our book does this ${ }^{15}$ - in fact, we make the opposite argument- that arts classes should NOT be adopted simply because they help language and math outcomes. Instead, arts classes should be included in education for their own sake as parts of a cultural and full education. Their helping of other non-arts domains is incidental to the primary reason why they should be included in education, and it's critical to both acknowledge that fact and to get the research right (not over or understated) on what the arts actually do for nonarts subjects. Artistic and theatrical skills have long been measured within the arts education forms themselves, although not formalized in a psychological context. Teachers are the best source here, as they have long had to provide grades and measurement of the skills learned in these classrooms. The most recent educational advice in the United States- the Every Student Succeeds Act includes Common Core Arts Standards ${ }^{16}$. This is the website: https://www.nationalartsstandards.org/ (I am not involved in this in any way).

Are you aware of initiatives where elements directly linked to the theatre are related to the so called behavioral skills? ${ }^{17}$ Are there specific OECD actions or plans that address or foster the arts and theatre education in world education?

Stéphan Vincent-Lancrin - In the Art for art's sake book, there are a few studies using theatre to go against anti-social behavior. There was also beginning evidence that theatre education developed empathy and perspective taking in students. One could imagine that it also develops a better emotional regulation, in part because it gets you to better study and understand how to render emotions - and thus what triggers them, etc. Also, many coaches in communication come from theatre, because there are a few important techniques that can be

${ }^{15}$ Interviewer's note: I think that my question was formulated in a way that generated this conflict, probably because I cited only mathematics and the mother tongue as examples. The fact that my epistemological frames, based on Gilles Deleuze's intensive philosophy, are different from that adopted in these studies also causes this, I believe. But this is not an issue to be addressed here, once I have already elaborated this approach in other articles of mine.

${ }^{16}$ https://www.nationalartsstandards.org/

${ }^{17}$ To complement this answer, please see Thalia Goldstein's papers listed in the references. 
transferred in the professional world, for example when people make presentations. Finally, like any living art, there is a dimension of stage fright that forces you to control your emotions when you perform. I guess you learn from that too.

\begin{abstract}
Many of OECD analysis concern on how to encourage teachers and students to have more motivation for education. Could you say something, in some strategies and some countries' policies, about components of therapy or at least some care for more broad or holistic personal development in education actions?
\end{abstract}

Ellen Winner - children tend to be more motivated and engaged in arts classes than other subjects as other subjects are often taught in a non-hands-on manner, where students sit passively and listen. Other subjects should borrow from the studio method of the arts to get kids involved in making projects during class time, while the teacher circles around for one on one consultation. This would likely increase student motivation and engagement.

Stéphan Vincent-Lancrin - One of the important aspects of arts education is that it works differently. Partly it is because it has become a low stage subject area for students in school. A "low stake" subject, an area where the stakes are low for learners. Often it is even seen as a recreational time to decompress after the more "important" subjects, at least in the sense that they will determine the academic and professional career of the majority of students. But partly it is just because the artistic disciplines tend to work differently with students - at their best. They give individualized feedback, they challenge students, they make them work on their emotions and go beyond them, they make them experience the state of flow by making them work on things they like but are challenging, etc. This is what colleagues showed in their book Studio Thinking (about visual arts education) (HETLAND et. al., 2007). In many ways, the strength of arts education is not to be found in how it transfers into other domains, but how it provides a method for better teaching and learning. There is bad arts education too though. And this brings to my mind two French movies with a few scenes on arts education: a beautiful relationship between students and their theatre teacher in Rivettes' 
"Gang of four" (La bande des quatre); a first very nice relationship turning sour in Abdel Kechiche's Games of Love and Chance (L'esquive), when the teacher becomes disappointed in her student and just lets him down. As everyone who has been through it knows, arts education can also be cruel and elitist, and finding the right level of challenge and engagement for students remains one of its difficulties, as is the case in any educational experience.

In the individual sphere, how do you see the articulation between preparing the student for the economic world and, at the same time, often in contradiction to this, to his capacity for self-determination, in which people do what they think as the best, in a way consistent with their ethical-aesthetic proposal of life?

Andreas Schleicher - I don't think this tension no longer exists in the world of today. Yes, you want to hire a competent engineer, but a competent engineer in the world of today is an ethical engineer. Again, in the age of artificial intelligence, we will need to think harder about how to educate first class humans. Technology and $\mathrm{Al}$ are not magic powers, they are just extraordinary amplifiers and accelerators that add speed and accuracy. Al will amplify good ideas and good practice in the same way it amplifies bad ideas and bad practice. Al is ethically neutral, but it is always in the hands of people who are not neutral. The only reason why we should fear the robots is because they will always obey us and never rebel.

The reality is that students sit most of the time behind individual desks and there is limited time for collaborative learning. That was made plain - and surprisingly so - in the results from the first PISA assessment of collaborative problem-solving skills in 2015. On average across OECD countries, fewer than one in ten 15-year-old students could complete problem-solving tasks that required them to maintain awareness of group dynamics, take actions to overcome obstacles and resolve disagreements with others, even when the content of these tasks was relatively simple.

More generally, changing skill demands have elevated the role of social and emotional skills. Such skills are involved in achieving goals, living and working with others and managing emotions. They include character qualities such as 
perseverance, empathy or perspective taking, mindfulness, ethics, courage and leadership. In fact, developing those kinds of characteristics was what distinguished many of the elite schools that I have visited. But for the majority of students, character formation in school remains a matter of luck, depending on whether it is a priority for their teacher, since there are very few education systems that have made such broader goals an integral part of what they expect from students.

Social and emotional skills, in turn, intersect with diversity in important ways. They can help students live and work in a world in which most people need to appreciate a range of ideas, perspectives and values, and collaborate with people of different cultural origins, often bridging space and time through technology; and a world in which their lives will be affected by issues that transcend national boundaries. Effective communication and appropriate behavior within diverse teams are also keys to success in many jobs, and will remain so as technology continues to make it easier for people to connect across the globe. Employers increasingly seek to attract learners who easily adapt and are able to apply and transfer their skills and knowledge to new contexts. Work-readiness in an interconnected world requires young people to understand the complex dynamics of globalization, and be open to people from different cultural backgrounds.

Engaging with different perspectives and world views requires individuals to examine the origins and implications of others' and their own assumptions. This, in turn, implies a profound respect for and interest in who the other is, their concept of reality and their perspectives. Recognizing another's position or belief is not necessarily to accept that position or belief. However, the ability to see through multiple lenses provides opportunities to deepen and question one's own perspectives and to make more mature decisions. Where we are not successful with this, we are building our education systems on sand. The bottom line is that we can try to assert boundaries, but we cannot hold them against the reality of interdependence. 


\section{References}

BIESTA, Gert. Interrupting the politics of learning. In: ILLERIS, Knud. Learning Theorists... In Their Own Words. New York: Routledge, 2018.

BORDEAUX, Marie-Christine (coordinatrice générale). L'évaluation des "effets " de l'éducation artistique et culturelle - Étude méthodologique et épistémologique (rapport finale). GRESEC - Université Grenoble Alpes / ECP - Université Lyon 2, août, 2016. Available in: https://recherche.univ-lyon2.fr/ecp/ressources/axe3/levaluation-des-effets-de-l2019education-artistique-et-culturelle-etudemethodologique-et-epistemologique/view

BOTTON, Alain de. The School of Life: An Emotional Education. London : Hamish Hamilton, 2019.

DAWSON, Katie, KIGER LEE, Bridget. Drama-based Pedagogy - activating learning across the curriculum. Bristol (England): Intellect Books, 2018.

HETLAND, Lois, WINNER, Ellen, VEENEMA, Shirley, SHERIDAN, Kimberly. Studio Thinking: The Real Benefits of Visual Arts Education. New York: Teachers College Press (Columbia University), 2007.

JOHNSON, Mark. The body in the mind - the bodily basis of meaning, imagination, and reasoning. Chicago: The University of Chicago Press, 1987.

LAKOFF, George. Women, fire, and dangerous things - what categories reveal about the mind. Chicago: The University of Chicago Press, 1987.

LAVAL, Christian. L'école n'est pas une entreprise: Le néo-libéralisme à l'assaut de l'enseignement public. Paris : La découverte, 2007.

OCDE (OECD). OECD Future of Education and Skills 2030. OECD Learning Compass 2030 - A Series of Concept Notes. Paris: OECD Publishing, 2019. Available in : http://www.oecd.org/education/2030-project/teaching-andlearning/learning/learning-compass-

2030/OECD_Learning_Compass_2030_Concept_Note_Series.pdf

OCDE (OECD). Students' Well-Being. PISA 2015 Results (Volume /II). Paris: PISA, OECD Publishing, 2017. http://dx.doi.org/10.1787/9789264273856-en

OCDE (OECD). Skills for social progress: the power of social and emotional skills. Paris: OECD skills Studies, OECD Publishing, 2015. Available in : https://www.oecd.org/education/skills-for-social-progress-9789264226159en.html 
PEREIRA, Rodrigo da Silva. Proposições da OCDE para América Latina: o PISA como instrumento de padronização da educação. In: RIAEE - Revista IberoAmericana de Estudos em Educação, v. 14, n. esp. 3, p. 1717-1732, out., 2019. Available in: https://periodicos.fclar.unesp.br/iberoamericana/article/view/12756

SCHLEICHER, Andreas. World Class - How to Build a 21st-Century School System. Paris: OECD Publishing, 2018. Available in: https://www.oecd.org/education/worldclass-9789264300002-en.htm

UNITED KINGDOM. Oral evidence: Fourth Industrial Revolution. Witness: Andreas Schleicher. Tuesday 26 February 2019. House of Commons, 2019. Available in: http://data.parliament.uk/writtenevidence/committeeevidence.svc/evidencedocu ment/education-committee/fourth-industrial-revolution/oral/97393.html

VARELA, Francisco, ROSCH, Eleanor, THOMPSON, Evan. The Embodied Mind: Cognitive Science and Human Experience. Cambridge, Massachusetts: MIT Press, 1992.

VINCENT-LANCRIN, Stéphan, GONZÁLEZ-SANCHO, Carlos, BOUCKAERT, Mathias, DE LUCA, Federico, FERNÁNDEZ-BARRERA, Meritxell, JACOTIN, Gwénaël, Joaquin Urgel, VIDAL, Quentin. Desenvolvimento da Criatividade e do Pensamento Crítico dos Estudantes - O que significa na escola. São Paulo: Fundação Santillana, 2020. Available in https://fundacaosantillana.org.br/2020/03/05/desenvolvimento-dacriatividade-e-do-pensamento-critico-dos-estudantes/

WINNER, Ellen, GOLDSTEIN, Thalia, VINCENT-LANCRIN, Stéphan. Art for Art's sake?: the impact of arts education. Paris: Educational Research and Innovation, OECD Publishing, 2013. http://dx.doi.org/10.1787/9789264180789-en . Versão resumida em espanhol Available in:

https://www.oecd.org/education/ceri/ES_ARTS_overview_V5_print.pdf

YDESEN, Christian (Editor). The OECD's historical rise in education - The formation of a global governing complex. Cham (Switzerland): Palgrave Macmillan, 2019.

Received: $19 / 06 / 2020$

Approved: 31/08/2020

Universidade do Estado de Santa Catarina - UDESC

Programa de Pós-Graduação em Teatro - PPGT

Centro de Arte - CEART

Urdimento - Revista de Estudos em Artes Cênicas

urdimento.ceart@udesc.br 